\title{
Coyote responses to changing jackrabbit abundance affect sheep predation
}

\author{
L. CHARLES STODDART, RICHARD E. GRIFFITHS, AND FREDERICK F. KNOWLTON
}

Authors were wildlife biologists, USDI, U. S. Fish and Wildlife Service, Denver Wildlife Research Center, Utah State University, Logan, Ut 84322-5295 during the time data were collected and the initial manuscript drafted.

\begin{abstract}
Domestic sheep ranchers generally perceive abundances of natural prey and coyotes (Canis latrans) as important factors affecting coyote predation rates on sheep. To determine the effect of a changing natural prey base on coyote predation rates, we estimated coyote density and predation rates on ewes and lambs during part of 1 cycle of black-tailed jackrabbit (Lepus californicus) abundance on a $2,300 \mathrm{~km}^{2}$ area of the Idaho National Engineering Laboratory in southcentral Idaho from 1979-1985. We used 100, 1.6-km scat collection lines and 80, 1.6-km flushing transects to assess coyote and jackrabbit densities, respectively. Ewe and lamb loss rates were determined from questionnaires sent to all 13 producers grazing sheep on the area. Spring coyote density varied from 0.10 to 1.39 coyotes $\mathrm{km}^{-2}$ in response to a systematic fluctuation in jackrabbit density from 0 to 243 jackrabbits $\mathbf{k m}^{-2}$. Reported total loss rates of ewes and lambs varied from 2.2 to 42.1 ewes $/ 10^{5}$ ewe-days and 33.0 to $163 \mathrm{lambs} / \mathbf{1 0}^{5}$ lamb-days and were linearly and directly related to coyote density $(P<0.005)$. Ewe and lamb loss rates were independent of jackrabbit density $(P>0.18)$ except for 1 year when jackrabbits were virtually absent from the study area and the loss of lambs escalated dramatically. Our data suggest the increased losses of lambs resulted from reduced buffering by natural prey.
\end{abstract}

Key Words: Canis latrans, Lepus californicus, sheep loss rate, coyote numerical response, buffering

Coyote (Canis latrans) predation on domestic sheep is a problem for many western sheep ranchers. Ranchers perceive coyote density and abundance of natural prey as important factors affecting predation rates on sheep (Gee et al. 1977, Nielsen 1977, Nass et al. 1984). Objective information concerning the relationships of these variables to coyote predation on sheep is limited largely because measuring and manipulating coyote and prey numbers is difficult. The effect of natural prey abundance on sheep predation is enigmatic because, while prey abundance can be an important

Portions of this study were conducted under the guidance and support of the U.S. Fish and Wildlife Service through Interagency Agreement No. DE-AI0781ID12315 with the Department of Energy. The Denver Wildlife Research Center transferred to the Animal and Plant Health Inspection Service (APHIS) of USDA on 3 March 1986 and later was transferred to Fort Collins, Colo, and renamed the National Wildlife Research Center.

Authors wish to thank M. R. Conover, F. H. Wagner, and L. A. Windberg for reviewing drafts of this manuscript.

Manuscript accepted 2 Apr. 2000.

\section{Resumen}

Los criadores de borregos domésticos generalmente perciben a la abundancia de presas naturales y coyotes (Canis letransI) como factores importantes que afectan las tasas de depredación de borregos por coyotes. Para determinar el efecto de una población cambiante de presas naturales en las tasas de depredación del coyote estimamos la densidad de coyotes y las tasas de depredación de ovejas y corderos durante parte de un ciclo de abundancia de liebres cola negra (Lepus californicus), el estudio se condujo de 1979 a 1985 en un área de $2,300 \mathrm{~km}^{2}$ del Laboratorio Nacional de Ingeniería de Idaho, situado en la parte sur-central de Idaho. Utilizamos 100 líneas "scat" de colección de $1.6 \mathrm{~km}$ y 80 transectos de abundancia de $1.6 \mathrm{~km}$ para evaluar las densidades de coyotes y liebres respectivamente. Las tasas de perdida de ovejas y corderos se determinaron mediante cuestionarios enviados a todos (13) los productores de borregos en apacentamiento del área. En primavera la densidad de coyotes vario de 0.10 a $1.39 \mathrm{~km}^{-2}$ en respuesta a una fluctuación sistemática de la densidad de liebres de 0 a 243 liebres $\mathbf{~ k m}^{-2}$. Las tasas de perdida total de ovejas y corderos reportadas por los productores vario de 2.2 a 42.1 ovejas $/ 10^{5}$ días-borrega y de 33 a 163 corderos $/ 10^{5}$ cordero-días y estuvieron lineal y directamente relacionados a la densidad de coyotes $(P<0.005)$. Las tasas de perdida de ovejas y corderos fueron independientes de la densidad de liebres $(P>$ 0.18), excepto en un año cuando las liebres estuvieron virtualmente ausentes del área de estudio y la perdida de corderos aumento dramáticamente. Nuestros datos sugieren que el aumento de perdidas de corderos resulta de la reducción en la acción de amortiguamiento que ofrecen las presas naturales.

determinant of coyote density (Clark 1972, Knowlton and Stoddart 1983, Knowlton and Gese 1995, Knowlton et al. 1999), natural prey can also buffer sheep against predation by coyotes (McAdoo 1975, Guthery 1977, Kaufeld 1977, Gober 1979).

We examined coyote predation rates on ewes and lambs during an irruption and decline in black-tailed jackrabbit (Lepus californicus) abundance in the northern Great Basin. Historically, jackrabbit numbers in this area have cycled dramatically (Wagner and Stoddart 1972, Gross et al. 1974). Jackrabbits also comprise a large fraction of coyotes' diet in this region and coyote numbers fluctuate in response to changing jackrabbit numbers (Clark 1972, Hoffman 1979, Johnson and Hansen 1979, and Knowlton and Stoddart 1992). 


\section{Materials and Methods}

\section{Study Area}

We conducted this study on the Idaho National Engineering Laboratory (INEL), a 2,300 $\mathrm{km}^{2}$ National Environmental Research Park $\left(43^{\circ} 40^{\prime} \mathrm{N} 112^{\circ} 30^{\prime} \mathrm{W}\right)$ in southcentral Idaho. The INEL is representative of the Northern Cold Desert Biome with big sagebrush (Artemisia tridentata Nuttall)-wheatgrass (Agropyron dasystachum Hooker) communities as the dominant association (Atwood 1970, Harniss and West 1973). Approximately 1,400 $\mathrm{km}^{2}$ of the periphery of the INEL was grazed by sheep and subjected to limited coyote removal by the U.S. Fish and Wildlife Service to control depredations. The interior portion was closed to domestic livestock grazing and to coyote removal. The entire INEL was closed to public trespass.

\section{Procedures}

In 1975, Denver Wildlife Research Center personnel initiated a study of coyote and jackrabbit population dynamics on the INEL. Indices of coyote and jackrabbit abundance were measured each spring and fall on a $1,200 \mathrm{~km}^{2}$ area, including grazed and ungrazed portions of the INEL (Davison 1980, L.C. Stoddart unpublished report). We converted the indices to estimates of density and used them as seasonal estimates for the grazed portion of the INEL.

Coyote indices were obtained using 100 , $1.6-\mathrm{km}$ scat collection lines randomly located along unimproved roads. Each spring and fall the lines were first cleared of scats and then newly deposited scats were counted and removed after 14 and 28 days. The index was the deposition rate of fresh scats (scats/km/day). We converted the indices to estimates of coyote density (no. $/ \mathrm{km}^{2}$ ) using the regression equation, density $=($ index -2.66$) \times 0.054$, developed in a mark-recapture study of coyote density on the INEL (Knowlton 1984). The coyote scat collection lines were not operated in spring 1979. This, and the following 4 years, were years of coyote population increase (L.C. Stoddart unpublished report). We estimated spring 1979 coyote density by averaging the ratios of spring to fall coyote density estimates for 1980 through 1983 (0.56) and multiplying the fall 1979 density estimate by this ratio.

Indices of black-tailed jackrabbit abundance were obtained using 80 , geographically fixed, 1.6-km line transects randomly located in the study area. Each spring and fall, each transect was walked between 0900 and 1600 hours when jackrabbits were generally sedentary. The perpendicu- lar distance from the transect line to the point from which each observed jackrabbit flushed was recorded and the data analyzed using program TRANSECT (Burnham et al. 1980). Because line transects walked in sagebrush habitat generally underestimate jackrabbit density by $41.5 \%$ (Wywialowski and Stoddart 1988), we multiplied the jackrabbit indices by 1.71 for our estimates of jackrabbit density. For estimates of coyote and jackrabbit density in winter, we used the mean of the preceding fall and succeeding spring density estimates.

Winter and spring sheep grazing and loss information were obtained from questionnaires sent to each rancher grazing sheep on the INEL from 1979 to 1985. Sheep monitored in this study generally lambed in February and grazed on the INEL for about 25 to 45 days from midApril to mid-June. Ewes returned to the INEL for about 50 days in December and January. We asked ranchers to provide numbers of lambs and ewes grazed, number of days grazed, and total numbers of lambs and ewes lost each spring and winter while on the INEL each year. We also asked them to estimate the numbers of lambs and ewes lost to coyote predation.

Loss rates of ewes and lambs for each ranch were calculated each year and season by dividing the reported number of ewes and lambs lost by the number of

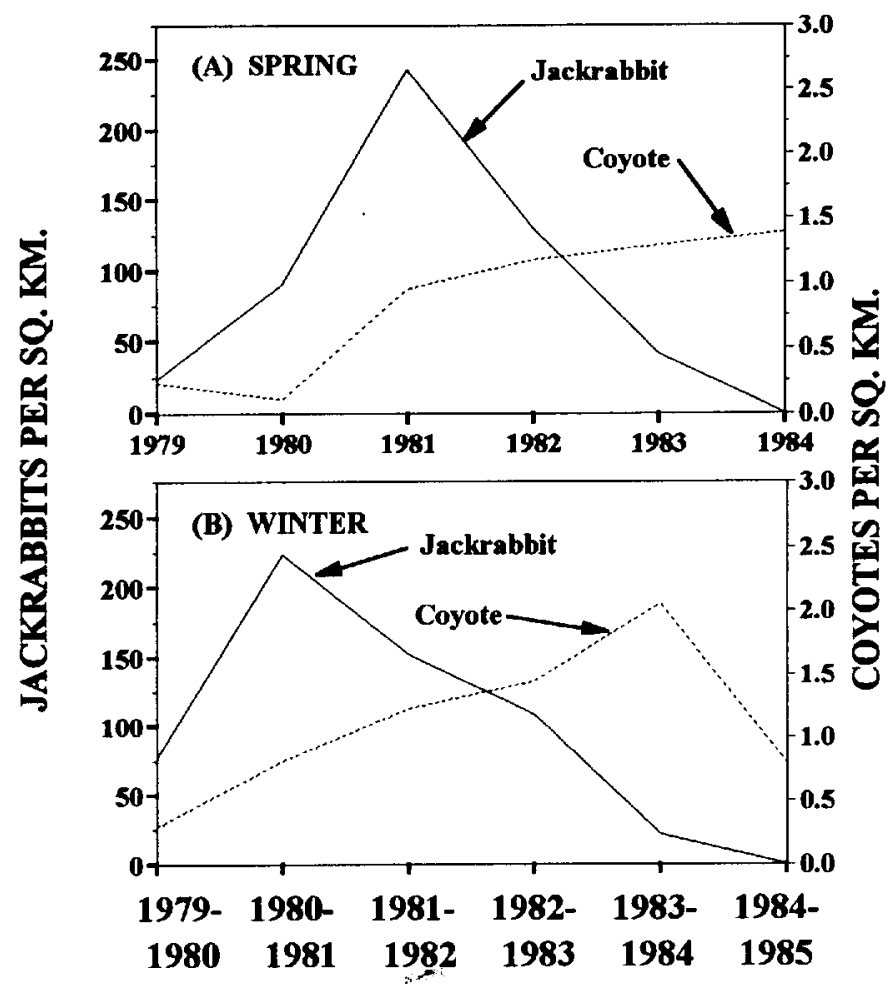

Fig. 1. Estimates of jackrabbit and coyote densities (numbers per $\left.\mathbf{k m}^{2}\right)$ in spring $(A)$ and winter (B). ewe- and lamb-days grazed respectively outlying estimates by first normalizing the distributions of pooled age and seasonal loss rates with the square root transformation and then using a sum-of-squares outlier test (Li 1964 p. 548). Weighted mean total loss rates were calculated similarly each year and season after pooling the data. We calculated weighted mean predation rates on lambs and ewes in like fashion using reported numbers of lambs and ewes killed by coyotes instead of total numbers lost. Linear regression analysis was used to evaluate the relationships between weighted mean coyote predation rates on ewes and lambs and coyote and jackrabbit densities.

\section{Results and Discussion}

\section{Jackrabbit Densities}

Between 1975 and 1978, prior to this study, jackrabbit abundance on the INEL steadily increased from near zero to about 12 jackrabbits $\mathrm{km}^{-2}$ (L. C. Stoddart unpublished report). The population continued to increase during the first 2 years of this study, peaked at about 225-250 jackrabbits $\mathrm{km}^{-2}$ in the winter to spring period 1980-81, and then declined steadily to near zero by spring 1984 (Fig. 1). on the INEL. Loss rates were tested for 


\section{Coyote Responses}

Coyotes responded both numerically and functionally to changes in jackrabbit abundance; their numbers increased coincident with increasing numbers of jackrabbits and composition of their diet included a much higher percentage of jackrabbit (MacCracken and Hansen 1987). From 1975 to 1978 coyote density was relatively low and constant at about 0.25 coyotes $\mathrm{km}^{-2}$ (L. C. Stoddart unpublished report). The population began to increase in 1979 , peaked at 2.1 coyotes $\mathrm{km}^{-2}$ in winter 1983-84, and declined to 0.79 coyotes $\mathrm{km}^{-2}$ the following winter (Fig. 1). The cycles we observed in abundances of coyotes and jackrabbits on the INEL are characteristic of coyote-jackrabbit cycles reported for northern Utah (Gross et al. 1974, Knowlton and Stoddart 1983, 1992). In northern Utah the proportion of jackrabbit in coyotes' diet changed markedly with changing jackrabbit abundance (Clark 1972, Hoffman 1979). Similarly, MacCracken and Hansen (1987), in a study concurrent with ours, reported the fraction of jackrabbit in the diets of INEL coyotes increased 15fold from low to high jackrabbit density, and during the latter, was the major source of coyote food. Changes in coyote abundance appeared to lag that of jackrabbits by 2-3 years (Fig. 1). Although the mechanics of changes in coyote abundance in response to changes in food base are not well understood, the lag may have resulted, in part, from a threshold effect (Wagner 1981). We suspect the functional response curve developed by Hoffman (1979) depicting coyote feeding patterns in relation to jackrabbit abundance in Curlew Valley, Utah (Fig. 2) is a more reasonable approximation of the form of this relationship. This suggests jackrabbit density in this area must reach 20-30 jackrabbits $\mathrm{km}^{-2}$ before the coyote population responds with increased density, and
Table 1. Number of ewes and lambs grazed and mean number of days grazed per sheep in spring and winter on the Idaho National Engineering Laboratory.

\begin{tabular}{|c|c|c|c|c|}
\hline \multirow{2}{*}{$\begin{array}{l}\text { Season: } \\
\text { Year }\end{array}$} & \multirow{2}{*}{$\begin{array}{l}\text { No. of operators } \\
\text { reporting }\end{array}$} & \multicolumn{2}{|c|}{ Animals grazed } & \multirow{2}{*}{$\begin{array}{c}\bar{x} \text { days grazed } \\
\text { per sheep }\end{array}$} \\
\hline & & Ewes & Lambs & \\
\hline & & ---- & $-\cdots$ & \\
\hline \multicolumn{5}{|l|}{ Spring: } \\
\hline 1979 & 5 & 14,500 & 20,780 & 27 \\
\hline 1980 & 7 & 13,343 & 19,838 & 30 \\
\hline 1981 & 8 & 17,692 & 20,186 & 32 \\
\hline 1982 & 9 & 21,986 & 27,296 & 45 \\
\hline 1983 & 6 & 14,029 & 20,291 & 30 \\
\hline 1984 & 5 & 11,482 & 15,662 & 26 \\
\hline Mean & 7 & 15,505 & 20,676 & 32 \\
\hline \multicolumn{5}{|l|}{ Winter: } \\
\hline $1979-80$ & 10 & 26,945 & & 63 \\
\hline $1980-81$ & 10 & 33,800 & & 57 \\
\hline $1981-82$ & 6 & 16,324 & & 56 \\
\hline $1982-83$ & 10 & 30,237 & & 44 \\
\hline $1983-84$ & 9 & 18,069 & & 38 \\
\hline $1984-85$ & 6 & 17,592 & & 47 \\
\hline Mean & 9 & 23,828 & & 51 \\
\hline
\end{tabular}

must decline to about the same level before the coyote population initiates a decline phase.

\section{Reported Sheep Losses}

Thirteen producers grazed sheep on the INEL during this study. Not all grazed the INEL each season and not all returned questionnaires for all seasons they did graze there. On average, spring estimates are based on reports from 7 producers, involving 15,505 ewes and 20,676 lambs, grazing for 32 days. Winter estimates were typically based on larger samples, on average involving 9 producers with 23,828 ewes grazed for 51 days (Table 1). Total sheep loss estimates and predation loss estimates are presented in Figure 3. In open range grazing situations, total loss estimates are considered more accurate than coyote predation estimates (Wagner 1988) because typically they are based upon counts of flocks entering and leaving grazing units. Estimates of predation loss-

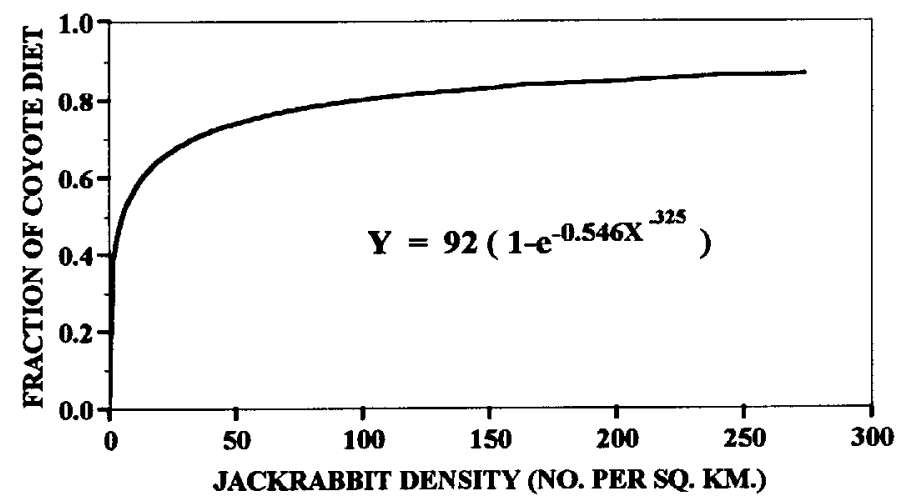

Fig. 2. Functional feeding response of coyotes to jackrabbit abundance (from Hoffman 1979) as the hypothesized buffering jackrabbits provide to sheep. es incorporate difficulties in locating carcasses as well as producer judgements in assigning causes of deaths. Predator killed carcasses are particularly difficult to locate on the open range (Lindzey and Wilbert 1989), and generally only a fraction are found by herders (Scrivner et al. 1985, Wagner 1988).

\section{Reported Coyote Predation Rates}

The weighted mean loss rates indicate the reported coyote predation rates of ewes and lambs on the INEL averaged 18 and $37 \%$ respectively of total loss rates of ewes and lambs. These values are generally lower than those reported in a variety of field studies of causes of sheep mortality (Wagner 1988). Also, the reported coyote predation rates on the INEL do not account for apparent systematic changes in total loss rates reported (Fig. 3). Unless mortality factors other than predation were varying in concert with changing coyote and jackrabbit numbers, which we consider unlikely, producers markedly underestimated true coyote predation rates on the INEL.

\section{Total Losses of Ewes and Lambs}

To circumvent problems associated with locating and properly assigning causes of death to sheep mortalities, we reasoned that if significant, systematic changes occurred in true coyote predation rates as coyote and jackrabbit densities fluctuated, they would be reflected by parallel changes in reported total loss rates. Consequently, we used reported total loss rates of ewes and lambs to estimate changes in predation rates rather than the reported predation rates themselves. The following discussion is based upon our 


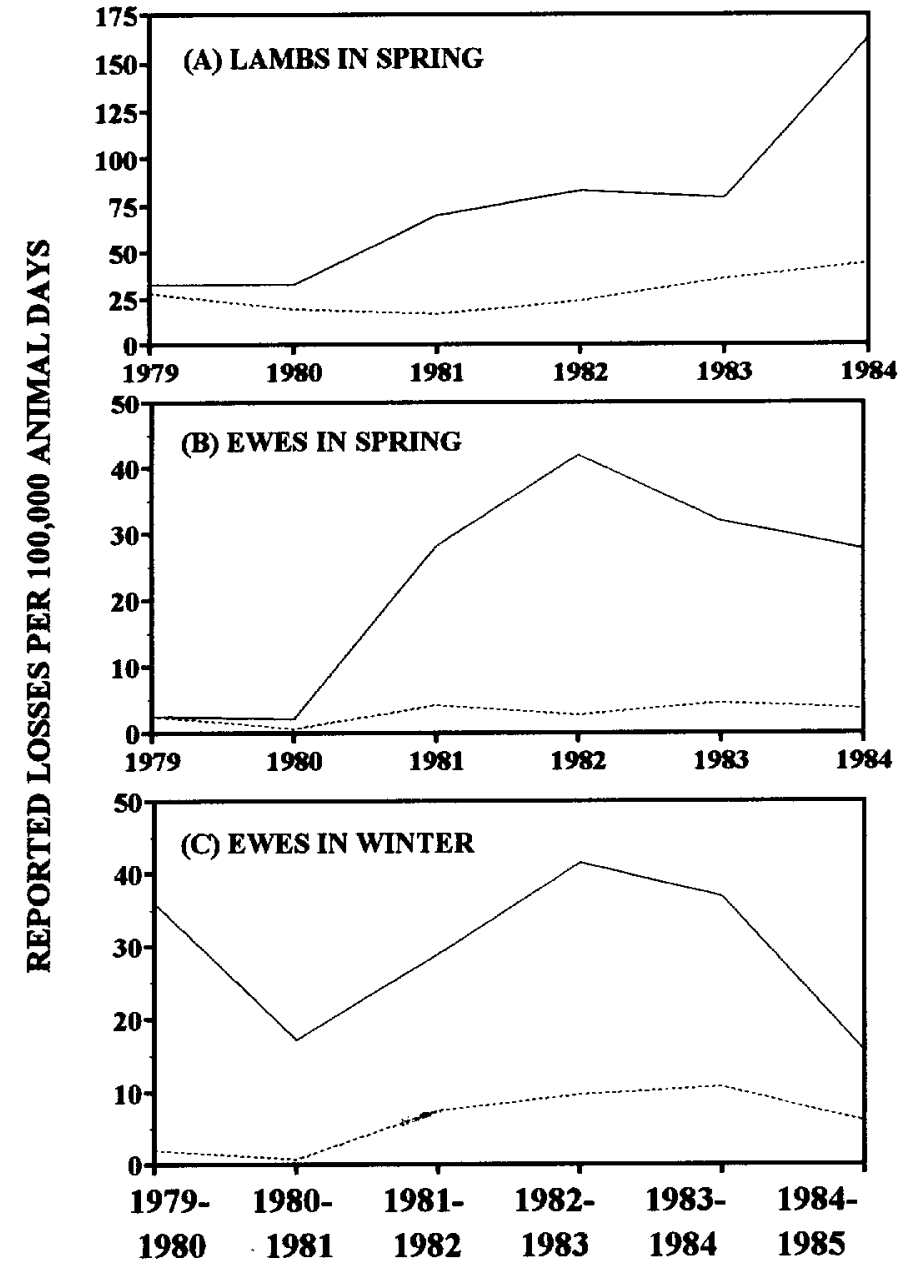

Fig. 3. Total and coyote predation loss rates (numbers lost per 100,000 sheep-days) for lambs (A) and ewes in spring (B) and winter (C) reported by ranchers grazing on INEL, 1979-1985.

analyses of total reported losses of ewes and lambs.

During this study, the weighted mean total loss rates (sheep lost per $10^{5}$ sheepdays grazed) ranged between 3 and 40 for ewes and 30 and 160 for lambs (Fig. 3). These are consistent with losses reported to the USDA Statistical Reporting Service (SRS) over 11 western states during the years of this study who reported average total postdocking losses of ewes and lambs of about 8 and $12 \%$ respectively (Wagner 1988). These would convert to loss rates (losses per $10^{5}$ animal days) of 22 and 80 , about mid-range for the total loss rates reported for the INEL.

Frequency distributions of loss rates of ewes and lambs, by individual ranchers and grazing season, pooled over the 6 years of study were skewed. These patterns are similar to that reported by Balser (1974), Nass et al. (1984), and others for predator losses, i.e. many ranchers report few or no losses while others report relatively high losses. In our study, individual
Since we did not measure parameters for individual ranches and could not account for individual loss rates, we pooled loss rates by age and season and used the weighted means for further analyses. Weighted means of reported total loss rates of ewes in spring and winter changed systematically from relatively low values early in the study, peaked in 1982, and declined the next 2 years (Fig. 3). A similar trend was noted in reported total lamb loss rates except for the last year of study (1984) when the total lamb loss rate escalated markedly (Fig. 3). The ratio of lamb loss rate to ewe loss rate changed systematically except for 1984 . Trends in predation rates reported for both ewes and lambs approximated those for total loss rates but generally at much lower rates (Fig. 3).

\section{Total Loss Rates}

The weighted mean total loss rate of ewes on the INEL in spring and winter was linearly correlated $\left(\mathrm{r}^{2}=0.75, \mathrm{P}<0.001\right)$ with estimated coyote density (Fig. 4). Inclusion of jackrabbit density as a second independent variable did not significantly improve the regression model $(\mathrm{P}>0.18)$ for ewes. The weighted mean total loss rate of lambs was also linearly correlated $\left(\mathrm{r}^{2}=\right.$ $0.68, \mathrm{P}<0.05)$ with estimated coyote density (Fig. 5a), but the regressional fit of the data was significantly improved with the addition of a term for the functional feeding response of coyotes to jackrabbit density (Fig. 5b). Although this model is supported by only 1 point, it is reasonable to expect a supersaturated coyote population to shift to alternate prey when its primary prey is no longer available. We approximated this by using the functional feeding response of coyotes to jackrabbit abundance (Fig. 2) developed by Hoffman (1979) to calculate the fraction of buffering jackrabbits might provide to sheep. This was achieved by dividing each estimate of coyote density by the functional feeding response of coyotes to jackrabbit abundance for that period and plotting this against reported lamb losses (Fig. 5b).

In the ewe and lamb total loss rate models (Figs. 4, 5), non-predation loss rates are inferred by the $\mathrm{Y}$ intercepts, with coyote predation accounting for losses above the intercept values. These models suggest total losses attributable to coyote predation ranging from 0 to $95 \%$; percentages consistent with sheep mortality studies where ranges or pastures were routinely searched on a periodic basis for dead sheep and the causes of death determined by trained personnel. In those studies coyote predation was generally implicated in the death of 


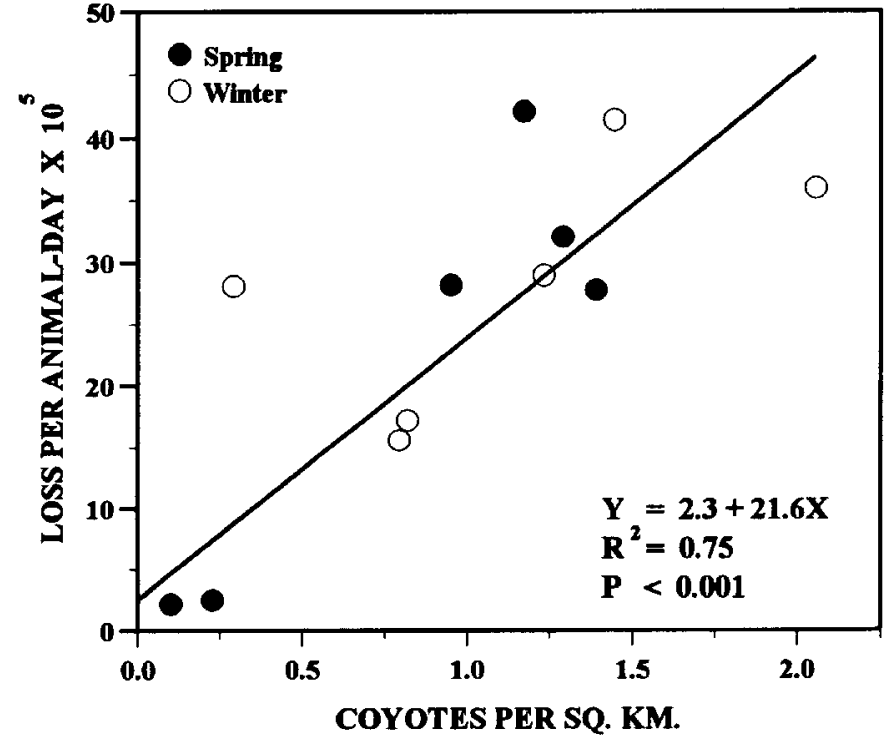

Fig. 4. Relationship between total loss rates of ewes (animals lost per 100,000 animal-days) and coyote density in spring (closed circles) and winter (open circles). Data point for winter 1979-80 ( $x=0.29, y=28.1)$ excluded from regression equation calculation.
While recent theoretical models of predator foraging behavior generally regard energetics as the most important factor in a predator's selection of prey items (Krebs et al. 1981), there also appears to be a foraging component that motivates predators to continually sample available food items, presumably to assess future optimum feeding strategies (Orians 1981). This may explain why coyotes on the INEL continued to kill sheep at a constant rate per coyote even when jackrabbits reached extremely high densities.

\section{Management Implications}

From the linear relationships between reported total loss rates of ewes and lambs and coyote density (Fig. 4, 5), we infer that predation rates on ewes and lambs are directly proportional to coyote abundance. From a management perspective, this suggests that reductions in coyote predation rates on ewes and lambs can be achieved
$30-90 \%$ of the postdocking ewe and lamb carcasses found (see reviews by O'Gara et al. 1983 and Wagner 1988). Neither coyote density nor abundance of prey were determined for those studies.

\section{Buffering by Jackrabbits}

The degree to which coyotes feed on natural prey when sheep are present represents buffering by natural prey. Although jackrabbits were an important part of the INEL natural prey base, marked changes in jackrabbit density during this study apparently did not affect the overall level of natural prey buffering of sheep as indicated by the linear relationships in Figures 4 and 5 . We hypothesize that buffering is not linearly related to abundance of natural prey, but likely of the form in Fig. 2 (Hoffman 1979). As prey abundance increases from low levels, buffering of sheep approaches an asymptotic level with the coyotes response to sheep unaffected by additional increases in natural prey. In spring 1984 jackrabbits virtually disappeared from the study site. For the first time during this study total prey abundance apparently fell below the level necessary to provide buffering of lambs at the asymptotic level. Although coyote density remained nearly unchanged from 1983 to 1984 , the reported total lamb loss rate doubled (Fig. 5). Because the total loss rate of ewes did not respond to the disappearance of jackrabbits in 1984, we believe the buffering curves for ewes and lambs are different and that a lower natural prey base is needed before reduced buffering occurs for ewes. More studies are necessary to clarify this buffering hypothesis.
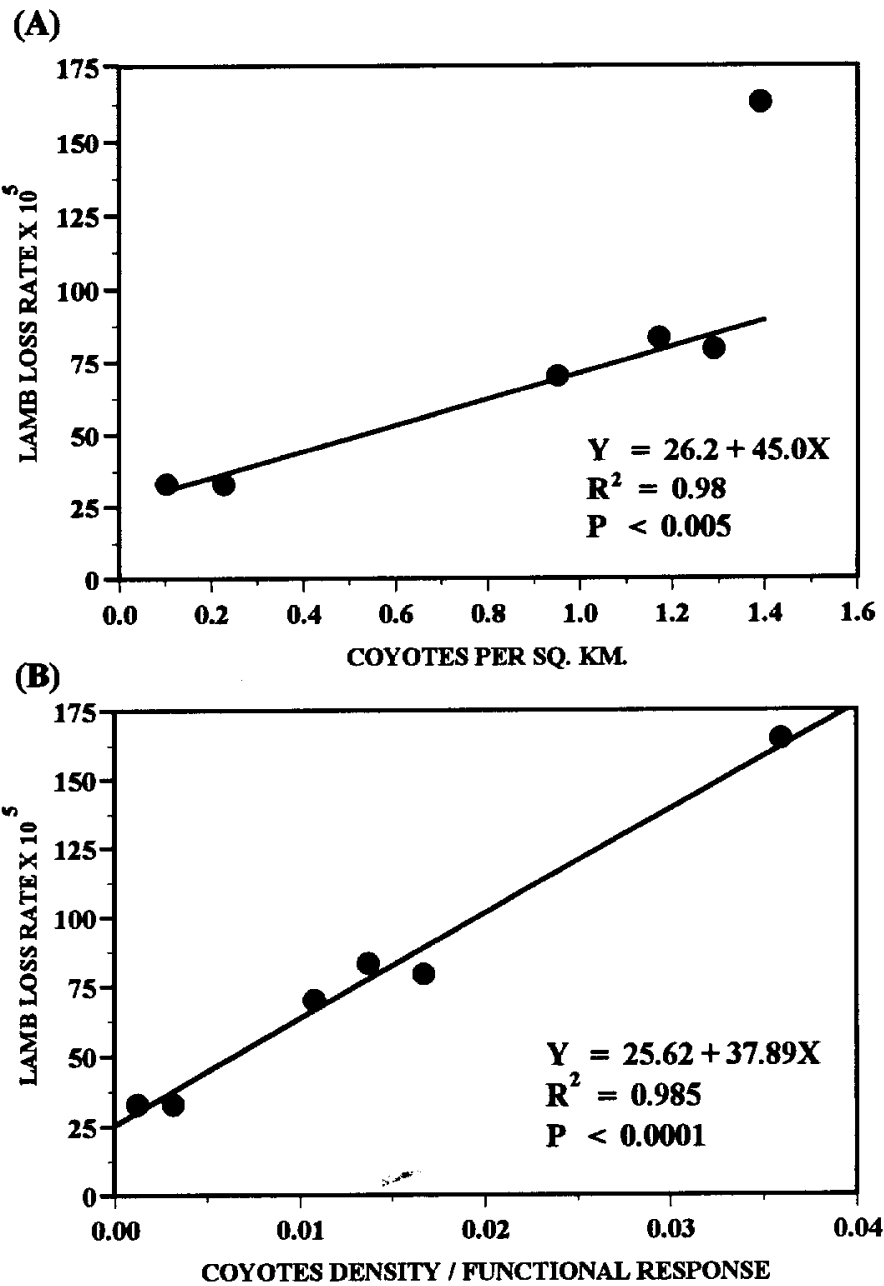

Fig. 5. Relationship between total loss rates of lambs (animals lost per 100,000 animal-days) and coyote density in spring on INEL, 1979-84, (A) without considering buffering by natural prey (data point for $1984[x=1.39, y=163]$ excluded from regression calculations), and (B) with inclusion of the functional feeding response of coyotes (from Hoffman 1979) as a measure of buffering provided by jackrabbits. 
in direct proportion to reductions in coyote abundance.

One alternative to coyote removal is reduction of coyote density through reduction in natural prey and carrion. This would be a preventive measure in which food reduction must be maintained. Some researchers (Weaver 1977, Todd and Keith 1976) suggest there is a critical period during the year, when food availability is lowest, that determines general coyote abundance on an area. Artificial reduction of the food base might be most effective in influencing coyote numbers if accomplished during such a critical period. The efficacy and feasibility of reducing food base as a means of depredation control in various habitats is currently unknown.

Because coyote density in the Great Basin fluctuates in response to cycles in jackrabbit abundance, changes in coyote predation on domestic sheep in this area are predictable. Application of this information can help sheep producers and depredation control personnel anticipate changing requirements to protect livestock and has the potential for substantially increasing the efficacy of depredation control programs. The most obvious aspect involves planning for the allocation of management resources. Generalization of this concept to other areas would depend on characteristics of the natural prey base and the relationship of coyote density to changes in prey abundance.

\section{Conclusions}

Coyote density on the INEL changed in direct response to a long-term cycle in jackrabbit abundance. Coyote predation rates on both ewes and lambs were linearly related to coyote density and were generally independent of jackrabbit abundance. However, when jackrabbits virtually disappeared from the study site, and availability of natural prey declined below the asymptotic level of our hypothesized prey buffering curve, predation rates on lambs increased beyond the level predicted by coyote density. Sheep producers on the INEL appear to have markedly underestimated coyote predation rates on ewes and lambs during the 4 years of this study when coyote density was relatively high. While conventional wisdom indicating a dramatic loss of natural prey results in increased predation on domestic stock appears correct, that same wisdom apparently does not recognize that numerical responses by coyotes associated with increased abundance of natural prey also results in increased predation on livestock.

\section{Literature Cited}

Atwood, N.D. 1970. Flora of the National Reactor Testing Station. Brigham Young University Science Bull., Biol. Series 11(4).

Balser, D.S. 1974. An overview of predationlivestock problems with emphasis on livestock losses. Trans. 39th N. Am. Wildl. Nat. Resour. Conf. 79:292-300.

Burnham, K.P., D.R. Anderson, and J.L. Laake. 1980. Estimation of density from line transect sampling of biological populations. Wildl. Monogr. 72:1-202.

Clark, F.W. 1972. Influence of jackrabbit density on coyote population change. J. Wildl. Manage. 36:343-356.

Davison, R.P. 1980. The effect of exploitation on some parameters of coyote populations. Ph.D. Diss., Utah State Univ., Logan, Ut.

Gee, C.K., R.S. Magleby, W.R. Bailey, R.L. Gum, and L.M. Arthur. 1977. Sheep and lamb losses to predators and other causes in the western United States. USDA Agr. Econ. Rep. 369.

Gober, D.R. 1979. Factors affecting domestic sheep losses to predators in Trans-Pecos, Texas. Ph.D. Diss., Texas A\&M Univ., College Station, Tex.

Gross, J.E., L.C. Stoddart, and F.H. Wagner. 1974. Demographic analysis of a northern Utah Jackrabbit population. Wildl. Monogr. 40:1-68.

Guthery, F.S. 1977. Efficacy and ecological effect of predator control in South Texas. Ph.D. Diss., Colorado State Univ., Fort Collins, Colo.

Harniss, R.O. and N.E. West. 1973. Vegetation patterns of the National Reactor Testing Station, southeastern Idaho. Northwest Sci. 47:30-43.

Hoffman, S.W. 1979. Coyote-prey relationships in Curlew Valley during a period of low jackrabbit density. M.S. Thesis, Utah State Univ., Logan, Ut.

Johnson, M.K. and R.M. Hansen. 1979. Coyote food habits on the Idaho National Engineering Laboratory. J. Wildl. Manage. 43:951-956.

Kauffeld, J.D. 1977. Availability of natural prey and its relationship to coyote predation on domestic sheep. M.S. Thesis, Univ. of Nev., Reno, Nev.

Knowlton, F.F. 1984. Feasibility of assessing coyote abundance on small areas. Unpubl. rpt. of Work Unit 909.01, Denver Wildl. Res. Ctr., Denver, Colo. 14pp.

Knowlton, F.F. and E.M. Gese. 1995. Coyote population processes revisited. In: D. Rollins, C. Richardson, T. Blankenship, K. Cannon. and S. Henke (eds.), Symposium Proc. Coyotes: a compendium of our knowledge. Texas A\&M Univ. Ext. Serv.

Knowlton, F.F., E.M. Gese, and M.M. Jaeger. 1999. Coyote depredation control: An interface between biology and management. J. Range Manage. 52:398-412.

Knowlton, F.F. and L.C. Stoddart. 1983. Coyote population mechanics: Another look, p. 93-111. In: F.L. Bunnel, D.S. Eastman, and J.M. Peek (eds.), Symposium of Natural Regulation of Wildlife Populations, Proc. No. 14, For. Wildl. Range Exp. Sta., Univ. Idaho, Moscow, Ida.
Knowlton, F.F. and L.C. Stoddart. 1992. Some observations from two coyote-prey studies. Pages 101-121 In: A. Boer, ed., Ecology and Management of the Eastern Coyote. Wildl. Res. Unit, Univ. New Brunswick, Fredericton.

Krebs, J.R., A.I. Houston, and E.L. Charanov. 1981. Some recent developments in optimal foraging, p. 3-18. In: A.C. Kamil and T.D. Sargent (eds), Foraging behavior: ecological, ethological, and psychological approaches. Garland Publishing Inc. New York.

Li, J.C.R. 1964. Statistical inference. Vol. I. Edwards Brothers, Inc., Ann Arbor, Mich.

Lindzey, F.G. and C. Wilbert. 1989. Estimating domestic sheep losses to mountain lions, p. 27-31. In: A.J. Bjugstad, D.W. Uresk, and R.H. Hamre (eds.), Ninth Great Plains Wildl. Damage Control Workshop Great Plains Agr. Council Pub. 127/USDA Forest Service Gen. Tech. Rpt. RM-171.

MacCracken, J.G. and R.M. Hansen. 1987. Coyote feeding strategies in southeastern Idaho: Optimal foraging by an opportunistic predator? J. Wildl. Manage. 51:278-285.

McAdoo, J.K. 1975. Predation on domestic sheep in northwestern Nevada. M.S. Thesis, Univ. of Nev., Reno, Nev.

Nass, R.D., G. Lynch and J. Theade. 1984. Circumstances associated with predation rates on sheep and goats. J. Range Manage. 37:423-426.

Nielsen, D.B. 1977. High/low predation-some why factors. Utah Sci. 38:82-86.

O'Gara, B.W., K.C. Brawley, J.R. Munoz, and D.R. Henne. 1983. Predation on domestic sheep on a western Montana ranch. Wildl. Soc. Bull. 11:253-264.

Orians, G.H. 1981. Foraging behavior and the evolution of discriminatory abilities, $\mathrm{p}$. 389-405. In: A.C. Kamil and T.D. Sargent (eds.), Foraging behavior: ecological, ethological, and psychological approaches. Garland Publishing Inc. New York.

Scrivner, J. H., W. E. Howard, A. H. Murphy, and J. R. Hays. 1985. Sheep losses to predators on a California range, 1973-1983. J. Range. Manage. 38:418-421.

Todd, A.W. and L.B. Keith. 1976. Responses of coyotes to winter reduction in agricultural carrion. Alberta Rec., Parks, Wildl. Dept. Fish Wildl. Div., Wildl. Tech. Bull. 5.

Wagner, F.H. 1981. Role of lagomorphs in ecosystems, p. 668-694. In: K. Myers and C.D. MacInnes (eds.), 1979 Proceedings of the world lagomorph conference, Univ. Guelph, Ontario, Canada.

Wagner, F.H. 1988. Predator control and the sheep industry. Regina Books, Claremont, Calif.

Wagner, F.H, and L.C. Stoddart. 1972 Influence of coyote predation on black-tailed jackrabbit populations in Utah. J. Wildl. Manage. 36:329-342.

Weaver, J.L. 1977. Coyote-food base relationships in Jackson Hole, Wyoming. M.S. Thesis, Utah State Univ., Logan, Ut.

Wywialowski, A.P. and L.C. Stoddart. 1988. Estimation of jackrabbit density: methodology makes a difference. J. Wildl. Manage. 52:57-59. 